\title{
Use of EIS for the evaluation of the protective properties of coatings for metallic cultural heritage: a review. ${ }^{1}$
}

\author{
Emilio Cano, Diana Lafuente and David M. Bastidas \\ Centro Nacional de Investigaciones Metalúrgicas (CENIM) \\ Consejo Superior de Investigaciones Científicas (CSIC) \\ Avda. Gregorio del Amo 8, 28040 Madrid \\ e-mail: ecano@cenim.csic.es
}

\begin{abstract}
The best way to reduce the degradation of metallic cultural heritage is through preventive conservation measures but, in many cases, it is not possible to obtain adequate environmental conditions, and it is necessary to apply coatings to the artefacts in order to protect them against corrosion. There is a continuous search in the metal conservation community for new and improved coatings that provide a better protection to the objects, while respect the special requirements of the conservation-restoration ethics. While electrochemical techniques have a long tradition in conservation-restoration treatments for metallic cultural heritage, the evaluation of protective coatings using electrochemical impedance spectroscopy (EIS) has only been used very recently. EIS is a very well established method to investigate metal coatings for general purposes, and have many advantages that make it especially suitable for testing coatings for metallic works of art. This paper makes a review of the use of EIS for testing coatings for metallic cultural heritage, from the first publications in the mid nineties of the last century to the last papers. The experimental setup used, the types of coatings and metals investigated and the interpretation of the results is reviewed and compared with the use of EIS for testing general purpose anticorrosive coatings.
\end{abstract}

Keywords: Metals, corrosion, protection, coating, electrochemistry, EIS , impedance, conservation, restoration.

\footnotetext{
${ }^{1}$ Published in J. Solid State Electrochem. 14 (2010) 381-391

DOI: $10.1007 / \mathrm{s} 10008-009-0902-6$

The final publication is available at www.springerlink.com
} 


\section{Introduction}

The main degradation phenomena that affect the metallic cultural heritage are the corrosion reactions with its environment: the burial soil, the outdoor atmosphere or the indoor environment of the museum, display cases or storage. The best way to avoid or at least delay such degradation is through preventive conservation. According to the Conservation Committee of the International Council of Museums (ICOM-CC), preventive conservation is defined as: "all measures and actions aimed at avoiding and minimizing future deterioration or loss. They are carried out within the context or on the surroundings of an item, but more often a group of items, whatever their age and condition. These measures and actions are indirect - they do not interfere with the materials and structures of the items. They do not modify their appearance" [1]. Thus, preventive conservation to prevent metal corrosion would include measures such as the reduction of the environmental relative humidity, the reduction of the pollutants, the use of vapour phase corrosion inhibitors, etc.

However, it is usually difficult, due to technical or economical reasons, to assure long term good conservation conditions for most of the objects, so it is a common practice to protect metallic artefacts against corrosion using protective coatings. Comparing with industrial applications, where the protective properties of the coating are the main parameter for their selection, when choosing coatings for conservation treatments for cultural heritage other properties should be considered:

- Visual appearance: Coatings should be transparent, with a similar gloss to the original substrate and should produce no or little change in the surface appearance.

- Reversibility: Any treatment applied to a cultural heritage artefact should be as reversible as possible, that is, it should be possible to remove it and return the object to its original state. That is not always possible, but it is an issue that should always be considered.

- Respect to the original object: Treatments should not modify the material of the original artefact. This includes, in most cases, the modifications suffered by the history of the object, such as patinas or corrosion layers, 
as far as they do not threaten the conservation of the object and its legibility.

- Long term efficiency and easy maintenance: Since heritage artefacts are intended to be preserved for a long time (as long as possible), any treatment should have long term efficiency. And since any coating will eventually be renewed, an easy maintenance is an advantage.

These considerations impose some important limitations in the selection and application of corrosion protection coatings: coatings should be not pigmented (what hinders their protective properties), should be usually applied over pre-existing corrosion products (making difficult a good adhesion and providing weak points for corrosion restart) and should be easily removable after many years without damage to the original.

A recent survey in the Mediterranean region has shown that, for the protection of historic metals in museums, conservators-restorers use mostly Paraloid B72 ${ }^{\mathrm{TM}}$ (an acrylic resin, dissolved in xylene, toluene or acetone) as protective coating, to a lesser extent, microcrystalline waxes, and in some cases combinations of both [2]. For outdoor bronzes, Incralac ${ }^{\mathrm{TM}}$ (an acrylic resin solution containing benzotriazole) is the most common protective coating [3-5]. However, failure of those coatings with severe damage to the underlying metal has been reported in many cases [6,7].

The testing of coatings for metallic cultural heritage also raises some additional difficulties when compared with coatings for industrial applications. The main one is the extreme variability in the substrates to which those coatings are to be applied, both because the different composition of the metallic substrate and because the different surface of the objects, ranging from the clean metal of industrial or scientific heritage to the more or less uniform patina of outdoor bronze sculptures or to the thick crust of corrosion products of archaeological objects. For this reason, in many cases there is a need of studying the performance of the coating applied on the object itself. On the other side, when there is a need for studying coatings in the laboratory, it is difficult to prepare metal coupons reproducing an historic or archaeological metal, covered with a layer of corrosion products developed over many years. Finally, those objects are exposed to very different environments, ranging from the very low corrosiveness of a controlled museum display case to the extreme corrosiveness of the outdoor exposure in 
very polluted areas. Considering all these special requirements for the coatings and the unique value of most of the objects composing the metallic cultural heritage, it is clear that there is a need in the metal conservation community for improved protection systems that can provide a better protection while fulfilling the conservation criteria $[8,9]$.

Electrochemical impedance spectroscopy (EIS) has been extensively used in the last three decades for the study of coatings for metals corrosion protection. EIS is especially suitable for the study of surfaces having a high electrical or electrochemical impedance and is, therefore, particularly suitable for the degradation evaluation of highly resistive protective organic coatings on metals. Additionally, it can provide not only a quantification of the protection capabilities of the coating but also provides information on the mechanisms involved in this protection and their degradation. However, the application of this technique for the evaluation of coatings for metallic heritage protection has been more recent and its use, in contrast to its application in industry, is not yet widely known and accepted.

The aim of this paper is to make a review of the use of electrochemical impedance spectroscopy for the study of protective coatings for metallic cultural heritage. A brief history of the use of different electrochemical techniques in metal conservation will be presented, followed by a short review of the use of EIS in general-purpose metal coatings studies, and finally a review of the applications of EIS in metal conservation studies will be detailed.

\section{History of the use of electrochemical techniques in metal conservation.}

Electrochemical techniques are mainly known in conservation and restoration of metallic heritage as a tool for treatment of the objects, involving the reduction of the corrosion products or the electrochemically aided removal of chlorides. In this field, it is usually distinguished between "electrolytic reduction", when the source of energy is an external source (a battery or generator) and "electrochemical reduction", when the source of energy is the formation of a galvanic cell between the object, acting as cathode, and a less noble metal, usually zinc or aluminium, acting as anode [10]. 
The history of the use of electrochemistry for the treatment of metallic cultural heritage dates back to the end of the XIX century, when Friedrich Rathgen begun to apply "electrolytic reduction" for treatment of active corrosion problems in archaeological bronzes and irons, using a potassium cyanide electrolyte and three Daniell cells in series. He was also a pioneer in the use of zinc granules for "electrochemical reduction" of bronze and copper coins [11]. Similar procedures were used during the first two thirds of the XX century, and were recommended for many restoration treatments for different metals in the famous Plenderleith's book "The Conservation of Antiquities and Works of Art" [10]. All those treatments were very radical, and removed all the corrosion products leaving only the clean metal surface.

Since the conservation-restoration criteria evolved and the importance of the corrosion products was recognized as part of the history of the object and, in many cases, the only remaining of the original surface or decorations, those radical treatments were abandoned in the 70 's- 80 's of the last century. Today, many conservators-restorers detest electrochemical techniques for the use of them that was made in those times. But it must be recognized that many other treatments (chemical, mechanical, thermal, etc.) have produced the same devastating effect, and the problem (from today's criteria point of view) were not the techniques used but the final result that was sought.

The inflection point in the progressive abandonment of electrochemical techniques in metal conservation was the publication of a paper by Carradice and Campbell on the treatment of lead objects [12]. The main innovation was the use of a three electrode cell allowing for potentiostatically controlled treatments. Since them, many authors have used this potentiostatic reduction for the treatment of lead [13,14], silver [15] and gilded silver [16]. For iron and copper based objects, electrochemical treatments have shown to be effective in the stabilization of archaeological objects though chloride removal, accelerating and improving the chloride removal when compared with traditional washing treatments [17-20].

Another application of electrochemistry for conservation of metallic cultural heritage that has gained popularity in recent times is its use for analytical purposes. Different authors have demonstrated the applicability of $E_{\text {corr }}$ monitoring, galvanostatic and 
potentiodynamic techniques for the identification of metals in alloys or components of a patina or corrosion products layer [21-29]. Some other applications of electrochemical techniques in metal conservation include the monitorization of the corrosion of objects in-situ or during their storage or treatment, or the cathodic protection of submerged or buried objects.

Polarization resistance measurements $\left(R_{\mathrm{P}}\right)$ or polarization curves have been also used for the evaluation of the protective character of different naturally or artificially grown patinas on bronze monuments [30-32], and protection systems such as inhibitors or conversion coatings for lead exposed to acetic acid environments [33,34] or iron [3537]. $R_{\mathrm{P}}$ has also been used as an alternative method to the "Oddy Test" for the evaluation of the potentially corrosive materials for their use in storage or display cases of metallic artefacts [38]. For all these applications, $R_{\mathrm{P}}$ has been recognized as a very valuable tool for the conservators-restorers, since it is a non-destructive technique that can provide quantitative values of corrosion rates, in a shorter time than natural exposure tests, giving them invaluable information for their selection of materials for the restoration or conservation of the objects.

A good indicator of the current importance of electrochemical techniques in metal conservation is the fact that this topic was one of the 5 themes selected for the working program of the Metal Working Group (WG) of the ICOM-CC in the triennial period 2005-2008. In the triennial meeting of the group, the Metal 07 conference held in Amsterdam in 2007, the communications were organized in the same themes. Table I shows the number of communications presented in each theme. It can be seen that 10 out of 60 communications $(17 \%)$ were in the "Use of electrochemical techniques in conservation" theme, what is a significant amount. But a deeper analysis of the other themes shows that electrochemical techniques have also been used in many papers presented in the other themes. Considering it, almost one third (19 out of $60,31 \%)$ of the communications have used electrochemical techniques for the study or the treatment of metal objects. 


\section{Use of EIS as a tool for studying the protective properties of metal coatings}

EIS is probably the most important electrochemical technique used for the investigation of coatings for metals corrosion protection, in industrial or decorative applications. A simple search in online databases such as ISI Web of Knowledge [39] or Scopus [40] with the terms "(eis OR impedance) and coating" yields more than 4000 results. Several extensive reviews on the application of EIS to coatings evaluation have been published, covering the different applications, the experimental details and the interpretation of results [41-46]. In this paper, only the main details that will be useful for the later comparison with the use of EIS for metallic heritage coatings will be detailed.

EIS is based on the application of a low amplitude alternating current (A.C.) voltage signal (usually 10-20 mV) to the coated metallic sample, using a conventional 3electrode (working, i.e., the coated metal under study; reference; and counter electrode) electrochemical cell $[42,44]$. Measuring the A.C. current response of the system, the impedance is calculated at different frequencies. A typical experiment is carried out making a logarithmic frequency swept from about $100 \mathrm{kHz}$ to a few $\mathrm{mHz}$, acquiring 510 points per decade $[42,44]$.

The typical electrochemical cell for coated metals consists in a vertical cylinder containing the electrolyte and the reference and counter electrodes, attached to the horizontal coated flat metal sample (Fig. 1). However, variations on this configuration have been employed for testing different geometries [45] or in combined experiments $[47,48]$.

EIS data of coated metals are usually represented using Bode plots, which display the logarithm of the impedance modulus, $|Z|$, and phase angle, $\varphi$, versus the logarithm of the frequency (Fig. 2). This plot has the advantage of being able to represent large variations in the $Z$ values. Other authors have used Nyquist plots(Fig. 3), which represent more clearly features such as diffusion effects, to represent EIS data of coated metals $[43,46,48,49]$. 
For the interpretation of EIS results, equivalent electrical circuits are usually employed. Those circuits are analogs that reproduce the electrical properties of the system [50]. The different elements of the equivalent electrical circuit are assigned to different physical elements of the system under study, but there is no one-to-one correspondence between the EIS data and the equivalent circuit, and different circuits can be employed to model the same results [49-52]. Nevertheless, equivalent electrical circuits have proven to be useful to study the behaviour of the coatings and the evolution of different properties involved in the corrosion process [53-55]. Figure 2 shows typical Bode plots corresponding to a good, smooth and intact coating; two plots corresponding to a damaged coating were the electrolyte reaches the metal interface (one of them modelled using pure capacitors and the other using constant phase elements, CPE); and a plot corresponding to a coating where diffusive effects play a significant role. Figure 3 shows the same data represented in Nyquist diagrams. The intact coating is usually modelled using the equivalent circuit shown in Fig 4a. It is composed by a capacitor $C_{\text {Coat }}$ representing the capacitance of the coating, in parallel with $R_{\text {Coat }}$ corresponding to the resistance of the coating, in series with $R_{\mathrm{S}}$ corresponding to the resistance of the electrolyte. When the coating is damaged, and the electrolyte can reach the metal surface, the shape of the Bode and Nyquist plots change and the electrical equivalent circuit commonly used to model its behaviour is the one shown in Fig $4 \mathrm{~b}: C_{\text {Coat }}$ and $R_{\mathrm{s}}$ have the same meaning, $R_{\text {Po }}$ models the resistance or ionically conducting paths across the coating ("pores"), $C_{\mathrm{DL}}$ models the double-layer capacitance and $R_{\mathrm{P}}$ models the polarization resistance of the corrosion process at the metal-electrolyte interface. It is common to find that ideal capacitors are not able to model experimental data, in cases such as non-uniform coatings, surface roughness or inhomogeneous distributions of the current. In such cases, EIS data are commonly modelled using constant phase elements instead of pure capacitors (Fig. 4c). The impedance of a CPE is defined by the empirical expression:

$$
Z_{\mathrm{CPE}}=\frac{1}{Y \omega^{2}}
$$

where $Y$ is a constant, $\mathrm{j}=(-1)^{1 / 2}, \omega=2 \pi f$, and the exponent $\alpha$ is $-1 \leq \alpha \leq+1$. When $\alpha=0$, the $\mathrm{CPE}$ is equivalent to a resistor; when $\alpha=1$, the CPE is equivalent to a capacitor; and when $\alpha=-1$, the CPE is equivalent to an inductor. Finally, if $\alpha=0.5$, the CPE is 
equivalent to the Warburg impedance. Warburg impedance is an element that models the impedance associated to diffusion (i.e., mass transfer) processes, and is commonly used when the diffusion of species through the pores of the coating or corrosion products controls the corrosion rate, producing a distinctive $45^{\circ}$ tail in the low frequencies region of the Nyquist plot (Fig. 3) [43,44,49,56,57]. A typical circuit modelling diffusive processes is shown in Fig. $4 \mathrm{~d}$.

Circuits shown are simplified models that in many cases can help to explain the experimental results but, in other cases, the EIS diagrams are more complex and other more sophisticated equivalent electrical circuits have been proposed, including additional $R$ - $C$ subcircuits $[15,58]$, or several $R$ - $C$ circuits in parallel modelling different areas or a multilayer coating [59].

The evolution of the different elements in the model can help to study the evolution of the metal-coating system. Thus, $C_{\text {Coat }}$ given by the equation

$$
C_{\mathrm{Coat}}=\frac{\varepsilon \varepsilon^{0} A}{t}
$$

where $\varepsilon$ is the dielectric constant of the coating, $\varepsilon^{0}\left(8.85 \times 10^{-4} \mathrm{~F} \mathrm{~cm}^{-1}\right)$ is the dielectric constant of the vacuum, $A$ is the exposed area and $t$ is the thickness of the coating, is commonly used to evaluate the changes in the dielectric constant caused by water absorption or changes in the pigment/polymer proportions of the protective/decorative coatings [60]. The volume percentage of absorbed water $V_{\mathrm{H}_{2} \mathrm{O}}$ is usually calculated using

$$
V_{\mathrm{H}_{2} \mathrm{O}}=100 \frac{\log \left(C_{\mathrm{t}} / C_{\mathrm{t}=0}\right)}{\log 80}
$$

were $C$ represent the capacitances at time $t$ or initially $(t=0)$.

Typical EIS experiments for the evaluation of coatings usually measure the changes in EIS data with immersion time in the electrolyte, but can also be used to evaluate the 
changes in the protective characteristics of the coating submitted to accelerated degradation, such as UV [52], mechanical stress[48] or salt-fog chamber [59]. Additional refinements of the technique have been its use in combination with other techniques, such as quartz crystal microbalance or scanning Kelvin probe [61] or the application of the localized electrochemical impedance spectroscopy (LEIS) to the study of coatings $[62,63]$.

\section{EIS in coatings for metallic heritage}

We have seen that EIS has been extensively employed for the characterization and evaluation of metal coatings, and that electrochemical techniques have a long tradition in metallic heritage conservation, and their use has been growing in the last years. But in spite of these facts, the application of EIS for evaluation of coatings for metallic heritage has been quite recent and it is still far from being considered a standard.

The first significant publication (to the best knowledge of the authors) addressing this topic, taking into account the specific materials and special needs of metal conservation, is a paper presented by Price et al. in Metal 95, the International Conference on Metal Conservation of the ICOM-CC Metal WG. In this paper, several wax coatings for outdoor bronzes are characterized and its degradation upon immersion is studied using EIS [64]. These authors concluded in their study that EIS could be useful technique for the evaluation of coatings for bronze conservation and that it can be used for evaluation of outdoor statues.

The evaluation of different wax coatings by EIS was continued by these researchers in the next years, evaluating also commercial mixtures of waxes and corrosion inhibitors [65] or the combination of artificial patination with wax coatings [66]. Bierwagen et al. have also tested different traditional (mainly Incralac ${ }^{\mathrm{TM}}$ ) and innovative coatings for outdoor bronzes using EIS after artificial ageing of coupons [3,4,67]. These authors measured the EIS response after QUV (UV light/water condensation cycles) and Prohesion (fog/dry cycles) accelerated ageing tests, according to ASTM D5894 [68], and proposed a quantitative lifetime prediction model based on the evolution of the low frequency modulus of the impedance with time. McNamara et al. have studied the 
biodeterioration of Incralac ${ }^{\mathrm{TM}}$ and have characterized the evolution of the protective properties of this coating applied on bronze using EIS, with an electrochemical cell inoculated with microorganisms collected from a real monument [5]. Clare and Lins have tested a water-borne polyvinylidene fluoride coating as an alternative to Incralac ${ }^{\mathrm{TM}}$ using artificially patinated bronze coatings [69]. Another alternative to traditional coatings for the protection of archaeological bronze artefacts that has been proposed and characterized using EIS is the deposition of $\mathrm{SiO}_{2}$-like thin films using low pressure plasma [70].

Using an specially designed "contact-probe", Letardi et al. have performed in-situ EIS measurements for the evaluation of the protective character of microcrystalline waxes, acrylic based coatings (such as Incralac ${ }^{\mathrm{TM}}$ ), and organo-silanes, applied to patinated or clean bronze samples (both naturally and artificially weathered) and real monuments [23,71-73]. The patina has shown to have a significant effect on the protective efficiency of the coatings. Thus, EIS data for the same coatings show very different results when applied on clean, artificially patinated or naturally patinated bronzes $[65,72]$. Therefore, it is important to consider that a coating that behaves well on clean metal might have a poor performance on patinated metal and vice versa.

Due to the importance of bronze in metallic cultural heritage, coatings for this metal have received the most attention. However, coatings for other metals have also been investigated using EIS. Hallam et al. have tested different petrochemical coatings (filmforming coatings, waxes and oils) for their use for protection of historical steel [74]. They compared the performance of coatings using ASTM B117 salt spray test [75] and EIS, and found a good agreement except in one of the coatings, what was explained by the different type of exposure, immersion versus airborne mist. In a subsequent work, the authors modified the experimental setup to study thin oil films, testing the oils applied on thin steel rods instead of flat coupons [76]. Corrosion inhibitors, applied as "dry films", have also been tested as protection systems for historic steel artefacts [77,78]. Cano et al. have tested different traditional and innovative coatings for historical steel using EIS [79]. The main difference with previous works was that coatings were applied on pre-corroded steel coupons simulating historical objects. EIS results showed a good agreement with other accelerated exposure tests, but had the 
advantages of a shorter test time and provides information about the mechanisms or protection and coating failure $[9,79,80]$.

Protection coatings for silver and silver alloys have also been tested using EIS. While corrosion layers and patinas on copper and iron based metallic artefacts are usually preserved, and therefore the protection layers are to be applied over them, in the case of silver based objects it is usually desirable the elimination of any corrosion layer or tarnishing, and the coatings are applied on the clean surfaces. This fact makes silver very appropriate for the application of thin electropolymerized or self-assembled layers. The protective properties of electopolymerized poli(3-amino 1,2,4-triazole) and selfassembled hexadecane-thiol coatings applied on silver have been studied using EIS and reflectance measurements: the results showed that the thiol film provided a good protection and was colourless and do not modify the visual aspect, and therefore fulfil the already mentioned requirements of a coating for conservation of cultural heritage $[15,58] . \mathrm{SiO}_{\mathrm{x}}$ coatings applied by low-pressure plasma have also been proposed for protection of silver artefacts [81]. EIS results show that the layer can provide a moderate increase in the corrosion resistance of the silver, and have the main advantage of being applicable immediately after a $\mathrm{H}_{2}$ plasma reduction treatment for the elimination of the sulphide tarnishing [82]. With a different approach, looking for a coating easily applicable by conservators-restorers to objects of any size and shape, Vassiliou et al. have proposed the modification of the commonly used Paraloid B $72^{\mathrm{TM}}$ by incorporating nanometric-sized alumina particles. EIS results showed that the pigmented coating improved the protection of both clean and sulphide-tarnished coupons, but not when the surface was covered by $\mathrm{AgCl}$ [83].

Lead coatings had also received some attention. While lead is quite resistant to corrosion by typical outdoor pollutants, it is easily corroded when exposed to acetic acid vapours, that are quite abundant in some indoor environments, especially in closed display cases of museums $[84,85]$. Some protective coatings already developed for lead exposed to acetic acid have recently been characterized using EIS and spectroscopic techniques, allowing for a real time characterization of the growth of the coating thickness and its protective properties [86,87]. 
In most of the aforementioned studies, the experimental setup for the EIS measurements was similar to the EIS tests for general purpose coatings. The main differences are found in the type of coatings selected, that are mainly chosen by their appearance and not their outstanding protectiveness; the application methods, since usually coatings in conservation treatments are applied by hand, and most to the research on this topic is done on coatings applied in this way, albeit it is known that the performance of the coatings can be reduced; and the preparation of the samples, since in many cases coatings are applied on metals covered by patinas or corrosion layers. But in some cases modifications were introduced to adapt the experiments to the special requirements of the coatings or the samples. We will review now some of the most significant differences in the experimental details that have been made for the test of coatings for metallic cultural heritage.

As we have already mentioned, the unique characteristics of each object, and even different areas of the same object make very interesting carrying out the EIS measurements directly on the real artefact. With the focus of the in-situ evaluation of outdoor bronze works of art, Letardi et al. developed a "contact-probe" electrochemical cell that allowed for a direct evaluation of coatings applied to works or art [88,89]. This probe consisted in a counter electrode and pseudo-reference electrode made of AISI 316 stainless steel inserted in a cylinder of PTFE. A cleaning cloth is soaked in mineral water, fixed to the cell and placed in contact with the object or coupon to be tested $[71,72]$. An additional step in this direction has been the development of a hand-held, low cost impedance spectroscopy system incorporating in a single device the electronics for the measurement, the data acquisition system and the electrochemical cell [90,91]. The authors have demonstrated the applicability of their system for the in-situ study of metallic heritage evaluating by EIS the protective properties of the coatings applied to different areas of the railing of the Palazzo Reale in Torino [92]. Apart from these major modifications, other smaller changes that could be mentioned are the modifications in the typical flat cell were made by Price, to avoid damage to wax coatings [64] or the already mentioned thin steel rods used by Hallam instead the flat samples [76].

Concerning the electrolyte, most of the tests have been carried out using low concentration (typically $0.1 \mathrm{M}$ ) $\mathrm{NaCl}$ aqueous solutions [64-66,74,82,83]. The low concentrations are justified by the lower concentration of pollutants that are expected to 
be found in museums indoors. Dilute Harrison electrolyte $\left(0.35 \mathrm{wt} \%\left(\mathrm{NH}_{4}\right)_{2} \mathrm{SO}_{4}+0.05\right.$ wt $\% \mathrm{NaCl}$ in $\mathrm{H}_{2} \mathrm{O}$ ) has also been used to test the behaviour of coatings exposed to acid rain $[3,4]$. For the tests over real objects, Letardi argues that no external contamination should be incorporated to the object by the electrolyte, so she defends and have used in her work mineral water [23,71-73,88,89]. Finally, Hallam used $0.25 \mathrm{M} \mathrm{K}_{2} \mathrm{SO}_{4}$ for his tests of thin oil films [76], and Dowsett used acetic acid containing electrolyte for the test of coatings for lead [87].

EIS data are presented using both Bode (as it is common for general purpose metal coatings) and Nyquist plots. Nyquist plots can be preferable in some of these cases when there are not big differences in the impedance values of the different coatings, and other features (such as the depression of the semicircles or diffusion) can be better observed using this representation $[15,58,78]$. It should also be noted that, with few exceptions $[76,79,89]$, there is an unfortunate tendency to publish only the $|Z|$ data of the Bode plot, and the phase angle $(\varphi)$ data are missed. This practice should be avoided since phase angle can provide very valuable information, and some parameters that can be directly obtained from this plot can be useful for the evaluation of the coating performance $[42,93]$.

Interpretation of the EIS data of coatings in the referred papers is usually based on a simple approach. Most of the works only evaluate the values of $|Z|$ at low frequencies, which in most cases is about $10-50 \mathrm{mHz}$, and its evolution with immersion time or exposure to accelerated test $[3,66,69,71-73,82,92]$. In some cases, the nested equivalent circuit (Fig. 3b) is used for fitting EIS data, but the values of the different components are not reported or a very limited discussion of the model and fitting values is made $[5,64,65,74]$. Finally, few of the most recent papers make a fitting and discussion of the equivalent circuit used, discussing the evolution of different values of the elements or the application of different models according to the different properties of the coatings $[15,56-58,76,78,79]$. Nevertheless, it should be recognized that the EIS data obtained from coatings applied following conservation practices (by hand, without a good control on the coating thickness and, in many cases, over pre-existing corrosion layers or patinas) yield complex diagrams showing depressed semicircles in the Nyquist plots or non-constant slopes in the Bode plots, that do not fit to the simple model of Fig. 4a. Some authors have used a constant phase elements (CPE) or Cole-Cole elements to 
model this dispersion of the time constants $[56-58,76,79,83]$. Diffusive effects have also been found by some authors; the EIS results corresponding to these effects are commonly modelled using the Warburg element [56,57]. Reproducibility is also a common issue in these measurements, that has been tackled by some authors making a statistical treatment of multiple data [71-73].

\section{Conclusions}

While EIS has been extensively used for testing anti-corrosive properties of metal coatings for almost 30 years, its application to the evaluation of coatings for conservation of metallic cultural heritage has been much more recent. In this field, EIS has begun to be used in the last years of the last century. Since then, its use has gained popularity and has been used for testing many different types of coatings for bronze, iron, silver or lead. The methodology has been adapted to the special requirements of the heritage artefacts and the requirements of the conservation professionals.

EIS has demonstrated to be a very useful and valuable tool to help the conservatorsrestorers to choose the most appropriate coating for the conservation purposes. It can be used in specially prepared coupons or in-situ on the heritage artefacts to evaluate the protective character of the coatings or the natural or artificial patinas. Its application in this specific field will probably increase in the next years, and it is desirable that the new developments in the technique and the interpretation of the results made by corrosion and coatings scientists and electrochemists would be applied to this specific field through an interdisciplinary collaboration with the conservation-restoration professionals.

\section{Acknowledgements}

The authors would like to acknowledge Prof. José María Bastidas for his continuous support and advice. D.M. Bastidas acknowledges the CSIC for his contract under the program "I3P-Postdoctoral" funded by the European Union. 


\section{References}

1. ICOM-CC (2008) Terminology to characterize the conservation of tangible cultural heritage. http://www.icom-cc.org/54/document/terminology-to-characterize-theconservation-of-tangible-cultural-heritage-english/?id=368. Accessed 18 april 2009

2. Argyropoulos V, Giannoulaki M, Michalakakos GP, Siaotou A (2007) A survey of the types of corrosion inhibitors and protective coatings used for the conservation of metal objects from museum collections in the Mediterranean basin. In:

Argyropoulos V, Hein A, Abdel Harith M (eds) Strategies for Saving our Cultural Heritage. Proceedings of the International Conference on Conservation Strategies for Saving Indoor Metallic Collections., Cairo. TEI of Athens, pp 166-170

3. Bierwagen G, Shedlosky TJ, Ellingson LA (2004) Electrochemical studies of the protection of bronzes from corrosion by organic coatings. In: MacLeod I, Theile JM, Degrigny C (eds) Metal 2001: proceedings of the international conference on metals conservation, Santiago (Chile). Western Australian Museum, Welshpool, pp 291-296

4. Ellingson LA, Shedlosky TJ, Bierwagen GP, de la Rie ER, Brostoff LB (2004) Stud Conserv 49: 53

5. McNamara CJ, Breuker M, Helms M, Perry TD, Mitchell R (2004) J Cult Herit 5: 361

6. Sease C, Selwyn LS, Zubiate S, Bowers DF, Atkins DR (1997) Stud Conserv 42: 1

7. Siatou A, Argyropoulos V, Charalambous D, Polikreti K, Kaminari A Testing new coating systems for the protection of metal collections exposed in uncontrolled museum environment. In: Argyropoulos V, Hein A, Abdel Harith M (eds) Strategies for Saving our Cultural Heritage. Proceedings of the International Conference on Conservation Strategies for Saving Indoor Metallic Collections., Cairo. TEI of Athens, Athens, pp 115-120

8. Cano E, Barrio J, Bastidas DM, Fajardo S, Bastidas JM, et al. (2009) Proyecto PROMET: desarrollo de materiales y técnicas innovadores para el estudio y protección del patrimonio metálico. In: Barrio J, Cano E (eds) MetalEspaña '08. Congreso de conservación y restauración del patrimonio metálico. UAM-CSIC, Madrid, pp 74-79

9. Degrigny C (2008) The search for new and safe materials for protecting metal objects. In: Argyropoulos V (ed) Metals and Museums in the Mediterranean 
Interpreting, Preserving and Exhibiting. PROMET Project, Athens (Greece), pp $179-235$

10. Plenderleith HJ (1956) The Conservation of Antiquities and Works of Art. Oxford University Press, London, pp 216-223

11. Gilbert M (1987) J Am Inst Conserv 26: 105

12. Carradice IA, Campbell SA (1994) Stud Conserv 39: 100

13. Schotte B, Adriaens A (2006) Stud Conserv 51: 297

14. Barrio J, Cano E, Arroyo M, Pardo AI, Chamón J (2005) Investigación sobre el proceso de estabilización y limpieza por reducción potenciostática de un plomo epigráfico romano Investigación en Conservación y Restauración. II Congreso del Grupo Español del IIC, pp 133-140

15. Bernard MC, Dauvergne E, Evesque M, Keddam M, Takenouti H (2005) Corros Sci 47: 663

16. Degrigny C, Wéry M, Vescoli V, Blengino JM (1996) Stud Conserv 41: 170

17. Adriaens A, Dowsett M, Leyssens K, Van Gasse B (2007) Anal Bioanal Chem 387: 861

18. Dalard F, Gourbeyre Y, Degrigny C (2002) Stud Conserv 47: 117

19. Guilminot E, Baron G, Memet JB, Huet N, Le Noc E, et al. (2007) Electrolytic treatment of archaeological marine chloride impregnated iron objects by remote control. In: Degrigny C, Van Lang R, Joosten I, Ankersmith B (eds) Metal 07. Proceedings of the Interim meeting of the ICOM-CC Metal WG, vol 3, Amsterdam (The Neatherlands). Rijksmuseum Amsterdam, Amsterdam, pp 38-43

20. Liu J, Li Y, Wu M (2008) Stud Conserv 53: 41

21. Costa V, Balliana E, Leyssens K, Adriaens A (2007) Identification of copper alloys constituting cultural artefacts using electrochemical techniques. In: Degrigny C, Van Lang R, Joosten I, Ankersmith B (eds) Metal 07. Proceedings of the Interim meeting of the ICOM-CC Metal WG, vol 5, Amsterdam (Netherland). Amsterdam, pp 22-25

22. Degrigny C, Crawford J, Debattista R (2007) The 'Drop' Ecorr vs time monitoring technique: a possible spot test for metal artefacts? In: Degrigny C, Van Lang R, Joosten I, Ankersmith B (eds) Metal 07. Proceedings of the Interim meeting of the ICOM-CC Metal WG, vol 3, Amsterdam (The Neatherlands). Rijksmuseum Amsterdam, Amsterdam, pp 71 
23. Letardi P, Luciano G (2007) Survey of EIS measurements on copper and bronze patinas. In: Degrigny C, Van Lang R, Joosten I, Ankersmith B (eds) Metal 07. Proceedings of the Interim meeting of the ICOM-CC Metal WG, vol 3, Amsterdam (Netherland). Amsterdam, pp 44-50

24. Bastidas JM, López-Delgado A, López FA, Alonso MP (1997) J Mater Sci 32: 129

25. López-Delgado A, Cano E, Bastidas JM, López FA (2001) J Mater Sci 36: 5203

26. López-Delgado A, Bastidas JM, Alonso MP, López FA (1997) J Mater Sci Lett 16: 776

27. Echavarría A, Rueda A, Cano E, Echeverría F, Arroyave C, et al. (2003) J Electrochem Soc 150: B140

28. Doménech-Carbó A, Doménech-Carbó M, Martínez-Lázaro I (2008) Microchim Acta 162: 351

29. Cano E, Polo JL, La Iglesia A, Bastidas JM (2005) Corros Sci 47: 977

30. Bartuli C, Cigna R, Fumei O (1999) Stud Conserv 44: 245

31. Rosales B, Vera R, Moriena G (1999) Corros Sci 41: 625

32. Bartolini M, Colombo B, Marabelli M, Marano A, Parisi C (1997) Non-destructive tests for the control of ancient metallic artifacts. In: MacLeod ID, Pennec SL, Robbiola L (eds) Metal 95. Proceedings of the International Conference on Metal Conservation, Semur-en-Auxois (France). James \& James, London, pp 43-49

33. Chiavari C, Martinia C, Polia G, Prandstraller D (2004) Conservation of organ pipes: protective treatments of lead exposed to acetic acid vapours. In: Ashton J, Hallam D (eds) Metal 04. Proceedings of the International Conference on Metal Conservation, Canberra (Australia). National Museum of Australia, pp 281-293

34. Rocca E, Rapin C, Mirambet F (2004) Corros Sci 46: 653

35. Greiner A, Hallam D, Thurrowgood D, Creagh D (2007) An investigation of a tannate based corrosion inhibitor regimen for the boiler or a $19^{\text {th }}$ Century operational paddle steamer PS Enterprise. In: Degrigny C, Van Lang R, Joosten I, Ankersmith B (eds) Metal 07. Proceedings of the Interim meeting of the ICOM-CC Metal WG, vol 5, Amsterdam (The Neatherlands). Rijksmuseum Amsterdam, Amsterdam, pp 64-70

36. Hollner S, Mirambet F, Rocca E, Steinmetz J (2007) Environmentally-friendly treatments for the protection of iron artefacts of the cultural heritage against atmospheric corrosion. In: Degrigny C, Van Lang R, Joosten I, Ankersmith B (eds) 
Metal 07. Proceedings of the Interim meeting of the ICOM-CC Metal WG, vol 5, Amsterdam (The Neatherlands). Rijksmuseum Amsterdam, Amsterdam, pp 64-70 37. Argyropoulos V, Charalambous D, Kaminari A, Karabotsos A, Polikreti K, et al. (2007) Testing of a new wax coating Poligen ES 91009 and corrosion inhibitor additives used for improving coatings for historic iron alloys. In: Degrigny C, Van Lang R, Joosten I, Ankersmith B (eds) Metal 07. Proceedings of the Interim meeting of the ICOM-CC Metal WG, vol 5, Amsterdam (The Neatherlands). Rijksmuseum Amsterdam, Amsterdam, pp 10-15

38. Reedy CL, Corbett RA, Burke M (1998) Stud Conserv 43: 183

39. ISI Web of Knowledge. www.isiwebofknowledge.com. Thomson Reuters. Accessed 21 April 2009

40. Scopus. www.scopus.com. Elsevier B.V. Accessed 21 April 2009

41. Murray JN (1997) Prog Org Coat 30: 225

42. Mansfeld F (1995) J Appl Electrochem 25: 187

43. Walter GW (1981) J Electroanal Chem 118: 259

44. Murray JN (1997) Prog Org Coat 31: 375

45. Rammelt U, Reinhard G (1992) Prog Org Coat 21: 205

46. Skerry BS, Eden DA (1987) Prog Org Coat 15: 269

47. Adriaens A, Dowsett M (2008) Surf Eng 24: 84

48. Darowicki K, Szocinski M (2004) J Solid State Electrochem 8: 346

49. Skale S, Dolecek V, Slemnik M (2007) Corros Sci 49: 1045

50. MacDonald DD (2006) Electrochim Acta 51: 1376

51. Wu X, Ma H, Chen S, Xu Z, Sui A (1999) J Electrochem Soc 146: 1847

52. Hinderliter BR, Croll SG, Tallman DE, Su Q, Bierwagen G (2006) Electrochim Acta 51: 4505

53. Bastidas JM, Polo JL, Torres CL, Cano E (2001) Corros Sci 43: 269

54. Polo JL, Cano E, Bastidas JM (2002) J Electroanal Chem 537: 183

55. Polo JL, Cano E, Kong DY, Bastidas JM (2002) Corrosion 58: 670

56. Chiavari C, Colledan A, Frignani A, Brunoro G (2006) Mater Chem Phys 95: 252

57. Chiavari C, Rahmouni K, Takenouti H, Joiret S, Vermaut P, et al. (2007) Electrochim Acta 52: 7760

58. Evesque M, Keddam M, Takenouti H (2004) Electrochim Acta 49: 2937

59. Lee SJ, Pyun SI (2007) J Solid State Electrochem 11: 829

60. Murray JN (1997) Prog Org Coat 31: 255 
61. Paliwoda-Porebska G, Rohwerder M, Stratmann M, Rammelt U, Duc LM, et al. (2006) J Solid State Electrochem 10: 730

62. Grundmeier G, Schmidt W, Stratmann M (2000) Electrochim Acta 45: 2515

63. Zou F, Thierry D (1997) Electrochim Acta 42: 3293

64. Price C, Hallam D, Heath G, Creagh D, Ashton J (1997) An electrochemical study of waxes for bronze sculpture. In: MacLeod ID, Pennec SL, Robbiola L (eds) Metal 95. Proceedings of the International Conference on Metal Conservation, Semur-enAuxois (France). James \& James, London, pp 233-241

65. Otieno-Alego V, Heath G, Hallam D, Creagh D (2001) Electrochemical evaluation of the anti-corrosion performance of waxy coatings for outdoor bronze conservation. In: Ashton J, Hallam D (eds) Metal 98. Proceedings of the International Conference on Metal Conservation, Draguignan-Figanières (France). James \& James, London, pp 315-319

66. Otieno-Alego V, Hallam D, Viduka A, Heath G, Creagh D (2001) Electrochemical impedance studies of the corrosion resistance of wax coatings on artificially patinated bronze. In: Ashton J, Hallam D (eds) Metal 98. Proceedings of the International Conference on Metal Conservation, Draguignan-Figanières (France). James \& James, London, pp 315-319

67. Bierwagen G (2008) J Coat Technol Res 5: 133

68. ASTM (1996) ASTM D5894-96 Standard Practice for Cyclic Salt Fog/UV Exposure of Painted Metal, (Alternating Exposures in a Fog/Dry Cabinet and a UV/Condensation Cabinet)

69. Clare TL, Lins PA (2007) Evaluation of fluorinated protective coatings for outdoor metals. In: Degrigny C, Van Lang R, Joosten I, Ankersmith B (eds) Metal 07. Proceedings of the Interim meeting of the ICOM-CC Metal WG, vol 5, Amsterdam (The Neatherlands). Rijksmuseum Amsterdam, Amsterdam, pp 8387

70. Angelini E, Grassini S, Solorzano O, Do Nascimento Campos G, De Caro T (2006) Appl Phys A Mater Sci Process 83: 485

71. Letardi P, Spiniello R (2004) Characterisation of bronze corrosion and protection by contact-probe electrochemical impedance measurements. In: MacLeod I, Theile JM, Degrigny C (eds) Metal 2001: proceedings of the international conference on metals conservation, Santiago (Chile). Western Australian Museum, Welshpool, pp 316319 
72. Letardi P (2004) Laboratory and field tests on patinas and protective coating systems for outdoor bronze monuments. In: Ashton J, Hallam D (eds) Metal 04. Proceedings of the International Conference on Metal Conservation, Canberra (Australia). National Museum of Australia, pp 379-387

73. Joseph E, Letardi P, Mazzeo R, Prati S, Vandini M (2007) Innovative treatments for the protection of outdoor bronze monuments. In: Degrigny C, Van Lang R, Joosten I, Ankersmith B (eds) Metal 07. Proceedings of the Interim meeting of the ICOMCC Metal WG, vol 5, Amsterdam (The Neatherlands). Rijksmuseum Amsterdam, Amsterdam, pp 71-77

74. Hallam D, Thurrowgood D, Otieno-Alego V, Creagh D, A. V, et al. (2004) Studies of commercial protective petrochemical coatings on ferrous surfaces of historical and museum objects. In: MacLeod I, Theile JM, Degrigny C (eds) Metal 2001: proceedings of the international conference on metals conservation, Santiago (Chile). Western Australian Museum, Welshpool, pp 297-303

75. ASTM (2007) ASTM B117-07 Standard Practice for Operating Salt Spray (Fog) Apparatus

76. Hallam D, Thurrowgood D, Otieno-Alego V, Creagh D (2004) An EIS Method for assessing thin oil films used in museums. In: Ashton J, Hallam D (eds) Metal 04. Proceedings of the International Conference on Metal Conservation, Canberra (Australia). National Museum of Australia, pp 379-387

77. Dermaj A, Chebabe D, Hammouch H, Goursa M, Hajjaji N, et al. (2007) Atmospheric corrosion inhibition of historical steel by FPTS formulation based on triazole-thione. In: Argyropoulos V, Hein A, Abdel Harith M (eds) Strategies for Saving our Cultural Heritage. Proceedings of the International Conference on Conservation Strategies for Saving Indoor Metallic Collections, Cairo. TEI of Athens, Athens, pp 143-148

78. Hammouch H, Dermaj A, Goursa M, Hajjaji N, Srrhiri A (2007) New corrosion inhibitor containing Opuntia ficus indica seed extract for bronze and iron based artefacts. In: Argyropoulos V, Hein A, Abdel Harith M (eds) Strategies for Saving our Cultural Heritage. Proceedings of the International Conference on Conservation Strategies for Saving Indoor Metallic Collections, Cairo. TEI of Athens, Athens, pp $149-155$

79. Cano E, Bastidas DM, Argyropoulos V, Siatou A (2007) Electrochemical techniques as a tool for testing the efficiency of protection Systems for historical 
steel objects. In: Argyropoulos V, Hein A, Abdel Harith M (eds) Strategies for Saving our Cultural Heritage. Proceedings of the International Conference on Conservation Strategies for Saving Indoor Metallic Collections, Cairo. TEI of Athens, Athens, pp 121-126

80. Degrigny C, Argyropoulos V, Pouli P, Grech M, Kreislova K, et al. (2007) The methodology for the PROMET project to develop/test new non-toxic corrosion inhibitors and coatings for iron and copper alloy objects housed in Mediterranean museums. In: Degrigny C, Van Lang R, Joosten I, Ankersmith B (eds) Metal 07. Proceedings of the Interim meeting of the ICOM-CC Metal WG, vol 5, Amsterdam (The Neatherlands). Rijksmuseum Amsterdam, Amsterdam, pp 31-37

81. D'Agostino R, Fracassi F, Palumbo F, Angelini E, Grassini S, et al. (2005) Plasma Process Polym 2: 91

82. Grassini S, Angelini E, d'Agostino R, Palumbo F, Ingo GM (2007) Advanced plasma treatment for cleaning and protecting precious metal artefacts. In:

Argyropoulos V, Hein A, Abdel Harith M (eds) Strategies for Saving our Cultural Heritage. Proceedings of the International Conference on Conservation Strategies for Saving Indoor Metallic Collections, Cairo. TEI of Athens, Athens, pp 127-131

83. Vassiliou P, Novakovic J, Samara K (2007) Copper alloys and silver artefacts protection by coatings with nano-alumina pigments. In: Argyropoulos V, Hein A, Abdel Harith M (eds) Strategies for Saving our Cultural Heritage. Proceedings of the International Conference on Conservation Strategies for Saving Indoor Metallic Collections, Cairo. TEI of Athens, Athens, pp 132-136

84. Cano E (2001) Efecto de los vapores de los ácidos acético y fórmico en la degradación y patinado del cobre [Ph.D. Thesis]. Universidad Complutense de Madrid, Madrid

85. Tétreault J, Cano E, Van Bommel M, Scott D, Dennis M, et al. (2004) Stud Conserv 48: 237

86. Adriaens A, De Bisschop F, Dowsett M, Schotte B (2008) Appl Surf Sci 254: 7351

87. Dowsett M, Adriaens A, Schotte B, Jones G, Bouchenoire L (2007) Real time spectrochemical growth and corrosion resistance monitoring of lead carboxylate coatings in an environmental cell (eCell). In: Degrigny C, Van Lang R, Joosten I, Ankersmith B (eds) Metal 07. Proceedings of the Interim meeting of the ICOM-CC Metal WG, vol 3, Amsterdam (The Neatherlands). Rijksmuseum Amsterdam, Amsterdam, pp 26-31 
88. Letardi P, Beccaria A, Marabelli M, D'Ercoli G (2000) Development of Electrochemical Impedance Spectroscopy as a tool for outdoors bronze corrosion characterization. In: $2^{\text {nd }}$ International Congress on Science and Tecnology for the Safeguard of Cultural Heritage in the Mediterranean Basin, Paris (France). Elsevier, Amsterdam, pp 407-411

89. Letardi P, Beccaria A, Marabelli M, D'Ercoli G (2001) Application of electrochemical impedance mesurements as a tool for the characterization of the conservation and protection state of bronze works of art. In: Ashton J, Hallam D (eds) Metal 98. Proceedings of the International Conference on Metal Conservation, Draguignan-Figanières (France). James \& James, London, pp 303-308

90. Angelini E, Carullo A, Corbellini S, Ferraris F, Gallone V, et al. (2006) IEEE Trans Instrum Measurement 55: 436

91. Carullo A, Ferraris F, Parvis M, Vallan A, Angelini E, et al. (2000) IEEE Trans Instrum Measurement 49: 371

92. Angelini E, Grassini S, Corbellini S, Ingo GM, De Caro T, et al. (2006) Appl Phys A Mater Sci Process 83: 643

93. Mahdavian M, Attar MM (2006) Corros Sci 48: 4152 


\section{Figure captions}

Fig 1. Electrochemical cell commonly used for testing metal coatings.

Fig. 2. Typical Bode plots corresponding to a good, smooth and intact coating; two plots corresponding to a damaged coating were the electrolyte reaches the metal interface (modelled using pure capacitors and $\mathrm{CPE}$ ); and a plot corresponding to a coating where diffusive effects play a significant role.

Fig. 3. Nyquist plots corresponding to the same data of Figure 2.

Fig. 4. Equivalent electrical circuits used to model EIS data of Figures 2 and 3. 
Table I: Number of communications in the different themes in the Metal 07 conference that use electrochemical techniques (ET).

Metal 07

Theme

Communications

Communications

using ET.

When archaeometry and conservation meet 15

Innovative investigation of metal artefacts

112

Study and conservation of composite artefacts

60

Protection of metal artefacts

$18 \quad 7$

Use of electrochemical techniques in metal conservation 10 10

Total (\%) $10(17 \%)$ $19(31 \%)$ 
Fig. 1

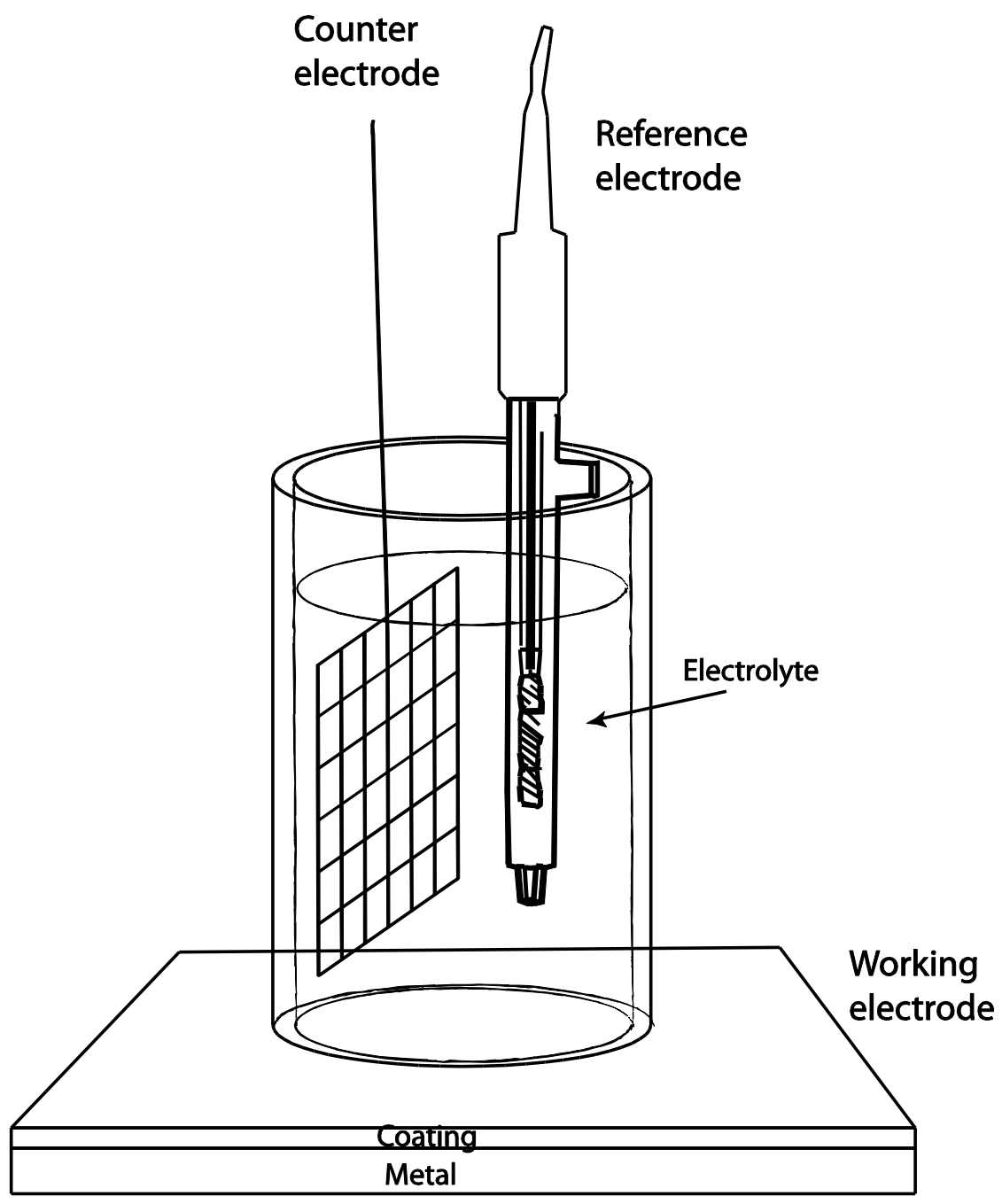


Fig 2

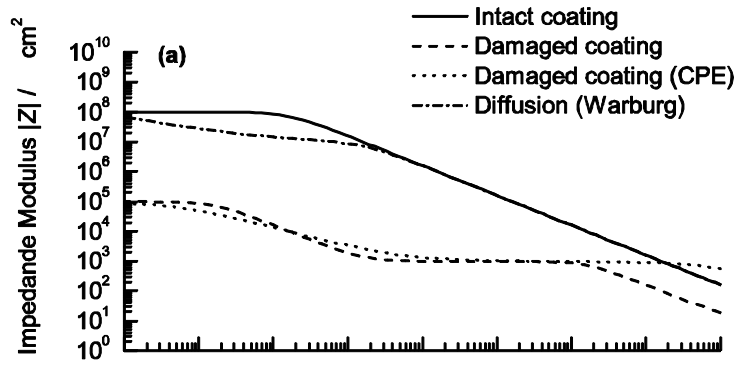

(b)

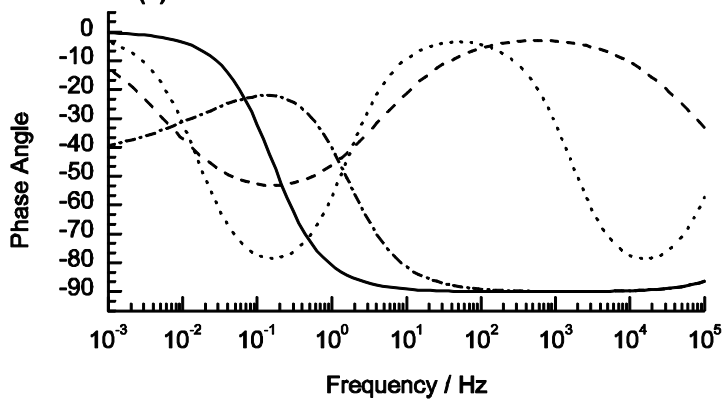


Fig 3
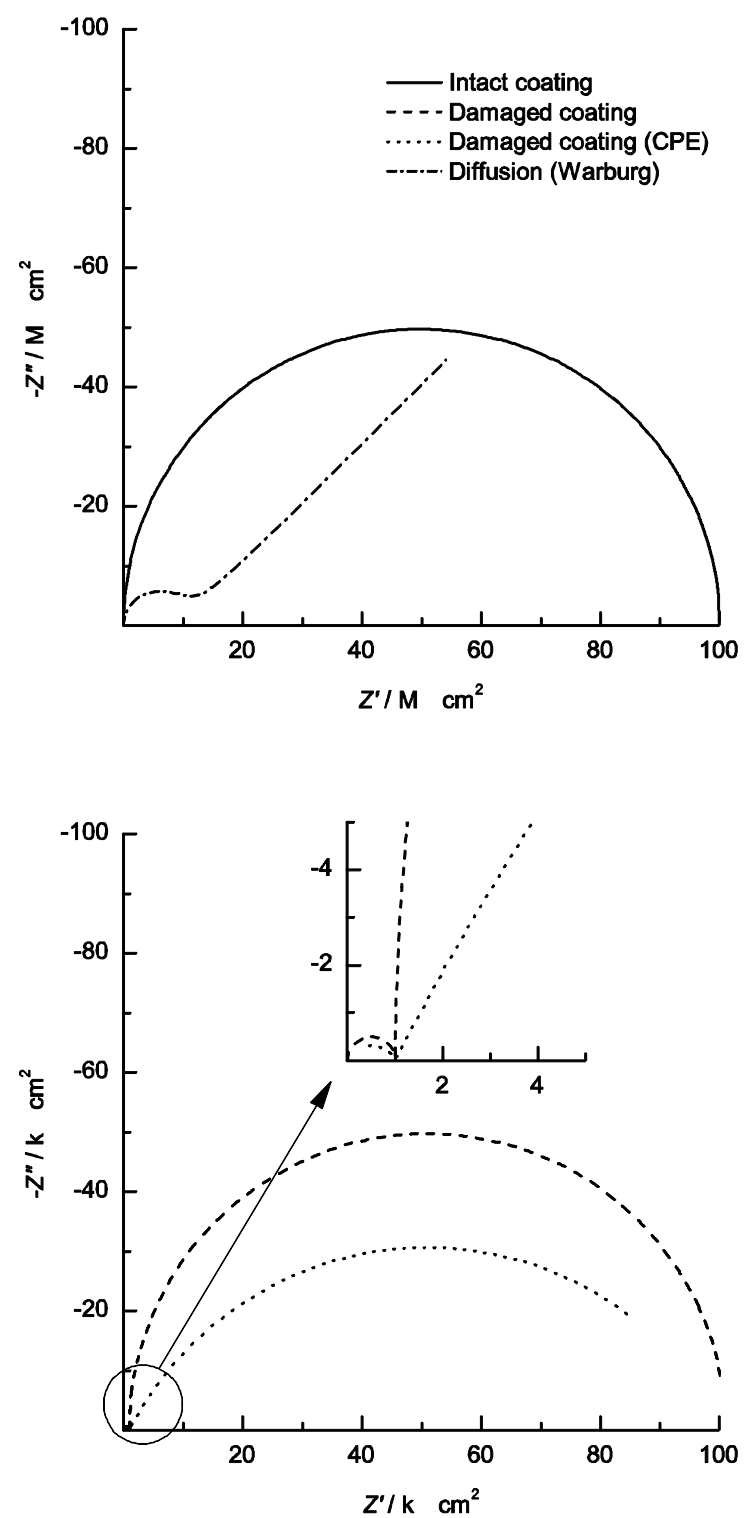
Fig 4.

(a)

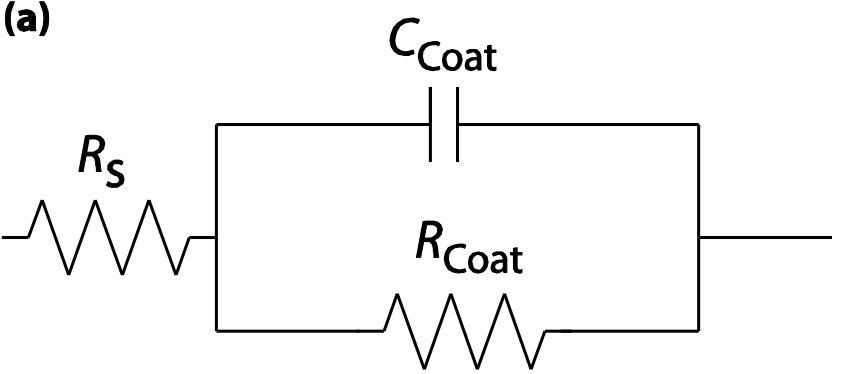

(b)

Coat

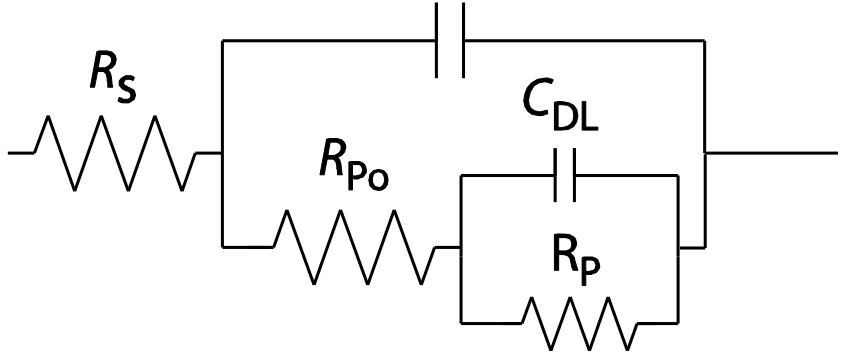

(c) $\quad C P E_{\text {Coat }}$

$\bigwedge \overbrace{\mathrm{S}}^{R_{1}}$

(d)

$C_{\mathrm{DL}}$

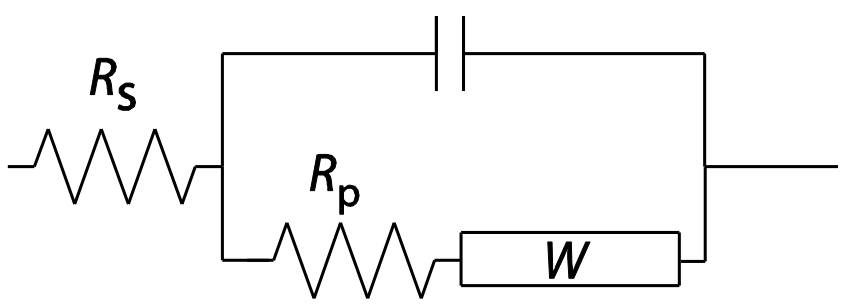

